Scientia Marina 85(2)

June 2021, 137-144, Barcelona (Spain)

ISSN-L: 0214-8358

https://doi.org/10.3989/scimar.05078.012

\title{
Intraspecific density effect on growth of Marphysa "sp." juveniles
}

\author{
João Pedro Garcês, Pedro Pousão-Ferreira \\ IPMA - Portuguese Institute for the Ocean and Atmosphere, EPPO Aquaculture Research Station, \\ Av. Parque Natural da Ria Formosa s/n, 8700-194 Olhão, Portugal. \\ (JPG) (Corresponding author) E-mail: jgarces@ipma.pt. ORCID iD: https://orcid.org/0000-0002-1684-4422 \\ (PP-F) E-mail: pedro.pousao@ ipma.pt. ORCID iD: https://orcid.org/0000-0001-6746-764X
}

\begin{abstract}
Summary: There is growing demand for the territorial tube-building genus Marphysa (Eunicidae: Polychaete), commonly known in Portugal as "goose", for use as fishing bait, and it is being harvested all around the world for that purpose. Effects of intraspecific density on juvenile growth were studied over a four-month period in laboratory facilities. Three polychaete densities (low, 50 worms; medium, 150 worms; and high, 250 worms) were used in a $0.25 \mathrm{~m}^{2}$ aquarium containing sandy sediment and recirculating water. Total length, dry weight and number of segments were recorded for $60 \%$ of the initial population. All polychaetes were also counted to determine mortality rate and territorial behaviour through the existence of body lesions and broken and regenerating posterior segments. The results obtained in this study showed that density had a significant effect $(\mathrm{p}<0.001)$ on growth rates in any of the densities studied and that growth was significantly higher at lower densities $(\mathrm{p}<0.001)$. For all density levels, estimated daily growth was higher in the first month, decreasing progressively over time. The high aggressiveness and territorial behaviour of Marphysa "sp." juveniles, well evidenced by the highest mortality $(35 \%)$ under high density and by the presence of worms with lesions under low density $(30 \%)$ observed in the first month, suggests that territoriality is probably the main factor involved in the organization and spatial arrangements of individuals within a population. Marphysa juveniles probably compete for burrow space. The results reveal that Marphysa juveniles have a very territorial and aggressive behaviour that should be considered if the species is used for aquaculture production. Additional studies are required to determine the density effects for different developmental stages.
\end{abstract}

Keywords: aquaculture; density; growth; Marphysa; polychaetes.

\section{Efecto de la densidad intraspecifica sobre el crecimiento de Marphysa "sp." juveniles}

Resumen: El poliqueto Marphysa "sp." (Eunicidae), comúnmente conocido en Portugal como "ganso", es muy utilizado en todo el mundo, como cebo para la pesca deportiva y profesional. Los efectos de la densidad intraespecífica sobre el crecimiento de los juveniles se estudiaron durante un período de cuatro meses en laboratorio. Se utilizaron tres densidades: baja (50 gusanos), media (150 gusanos) y alta (250 gusanos) en acuarios de $0.25 \mathrm{~m}^{2}$, con arena y agua en recirculación. Longitud total $(\mathrm{cm})$, peso seco $(\mathrm{g})$ y el número de segmentos se registraron en $60 \%$ de la población inicial. Se contaron también todos los poliquetos para determinar la tasa de mortalidad y comportamiento territorial a través de la existencia de lesiones corporales, segmentos posteriores ausentes o en regeneración. Los resultados obtenidos, mostraron que el crecimiento fue significativamente mayor en las densidades más bajas $(\mathrm{p}<0.001)$. Para todos los niveles de densidad, el crecimiento diario estimado fue mayor en el primer mes, disminuyendo progresivamente con el tiempo. La alta agresividad y comportamiento territorial de los juveniles de Marphysa "sp.", bien evidenciada en el primer mes, por la mayor mortalidad $(35 \%)$ verificada en la alta densidad y por la presencia de gusanos con lesiones en la baja densidad (30\%), sugiere que la territorialidad es probablemente el factor principal que regula la organización y distribución espacial de los individuos dentro de una población. En conclusión, los resultados obtenidos revelan que los juveniles de Marphysa "sp." tienen un comportamiento muy territorial y agresivo, que debe considerarse si la especie se utiliza para la producción acuícola. Se necesitan estudios adicionales para determinar los efectos de la densidad para diferentes etapas de desarrollo.

Palabras clave: acuicultura; densidad; crecimiento; Marphysa; poliquetos.

Citation/Como citar este artículo: Garcês J.P., Pousão-Ferreira P. 2021. Intraspecific density effect on growth of Marphysa "sp." juveniles Sci. Mar. 85(2): 137-144. https://doi.org/10.3989/scimar.05078.012

Editor: E. Mañanós.

Received: May 11, 2020. Accepted: March 2, 2021. Published: May 28, 2021.

Copyright: $\odot 2021$ CSIC. This is an open-access article distributed under the terms of the Creative Commons Attribution 4.0 International (CC BY 4.0) License. 


\section{INTRODUCTION}

The iteroparous and long-lived polychaete Marphysa "sp." used in this study, and originally described from the south coast of England, has been recorded from many localities around the world, often without an exhaustive description or deposition of voucher material (Hutchings and Karageorgopoulos 2003). This genus has a global distribution and is of considerable value in the bait industry worldwide. Recently, there has been some debate on whether this genus may in fact encompass a series of cryptic species from different geographical regions that are morphologically difficult to distinguish (Lewis and Karageorgopoulos 2008, Asmaa et al. 2018, Lavesque et al. 2019). Therefore, we prefer to use the genus until we have evidence that this species is Marphysa sanguinea (Montagu, 1813).

Competition for space and food are important structuring agents of populations of sediment-dwelling species and are therefore key factors in species distribution and community organization (Rosenberg et al. 1997). In areas where food is abundant, space can become a factor limiting population expansion. Several studies of infaunal marine soft-bottom species showed that individual growth, larval recruitment and survivorship are negatively affected by an increase in density (Reise et al. 2001, Safarik et al. 2006 and references therein). In the laboratory it has been shown that an increase in population density is usually associated with a decrease in fertility (Zajac 1996) and in territorial and food competition (Scaps et al. 1998, Grelon et al. 2006). However, intraspecific relations between benthic individuals, particularly among polychaetes, are more complex, with several factors interacting simultaneously. According to Lemieux et al. (1997), the ability to exploit a habitat depends on the ability to defend a burrow, and this ability is related to aerobic capacity. In addition to the intrinsic interest in annelid polychaetes as ubiquitous and highly abundant members of all marine benthic ecosystems, there is a growing demand for these organisms as fishing bait, so they are being commercially exploited all around the world (Watson et al. 2016, Cole et al. 2018), including Europe (Gambi et al. 1994, Olive 1999, Lavesque et al. 2017). They have also been introduced in integrated polycultures to help manage organic matter and waste produced by bivalves and fish (Batista et al. 2003). They are a natural source of proteins and omega-3 fatty acids, so they can be used as a nutritional resource and maturation diet in crustacean and fish aquaculture (Noda et al. 1994, Watson et al. 2016, Glasby et al. 2019). Therefore, in addition to the impacts of traditional bait harvesting (Carvalho et al. 2013), new mechanized methods of collection are being developed to increase efficiency, productivity and revenue (Beukema 1995, Birchenough 2013). The traditional bait digging exploitation continues to occur, presenting an ill-defined boundary between anglers collecting strictly for their own use and those collecting for profit, who represent a form of parallel economy in conflict with a controlled, sustainable use (Olive 1993, Cabral et al. 2019, Pombo et al. 2018).

\section{Potential uses}

Marphysa "sp.", commonly known by the name of "goose", is one of the most appreciated bait species among those collected and commercialized in Portugal because of its high resistance in the hook and its reputed ability to attract valuable fish species such as the seabreams Sparus aurata and Diplodus sargus. Though it is difficult to value this resource because the sales are not declared (Castro 1993), harvesting is one of the most important socio-economic resources for local fishermen, and sales of $€ 500000$ per year are estimated (unpublished data) (Garcês and Pereira 2010).

The long-term exploitation of this genus requires a good knowledge of the biological and ecological characteristics of natural populations in order to develop rearing techniques for intensive production with the aim of increasing supply, reducing harvesting and fostering sustainable use.

With this purpose in mind, a small-scale experiment was conducted in order to address the way in which intraspecific density can influence somatic growth in juveniles of Marphysa "sp." when food and sediment are not limiting factors. These effects were studied over a four-month period in laboratory facilities.

Further development of polychaete culture is considered of economic importance beyond that associated with the bait supply industry which acted as the initial catalyst for this research.

\section{MATERIALS AND METHODS}

A four-month on-site controlled experiment was conducted with Marphysa "sp." juveniles reared in the laboratory (25 to 30 setigerous segments corresponding to a total length of $0.7 \pm 0.05 \mathrm{~cm}$ to $0.9 \pm 0.08$ $\mathrm{cm}$, respectively). The juveniles were placed in glass aquaria $(0.5 \times 0.5 \times 0.5 \mathrm{~m})$ (Fig. 1$)$. Each aquarium was filled with a $6 \mathrm{~cm}$ layer of beach sand $(>95 \%$ fine grain $<50 \mu \mathrm{m}$ ). The sand was previously screened to remove macroalgae and any associated macrofauna, sun dried and then rinsed several times with freshwater and seawater alternately. It was further heated and sterilized in an autoclave. Before being added to aquaria that were randomly placed in the laboratory to reduce any position effects, the water was filtered through a biological filter and a cartridge series and

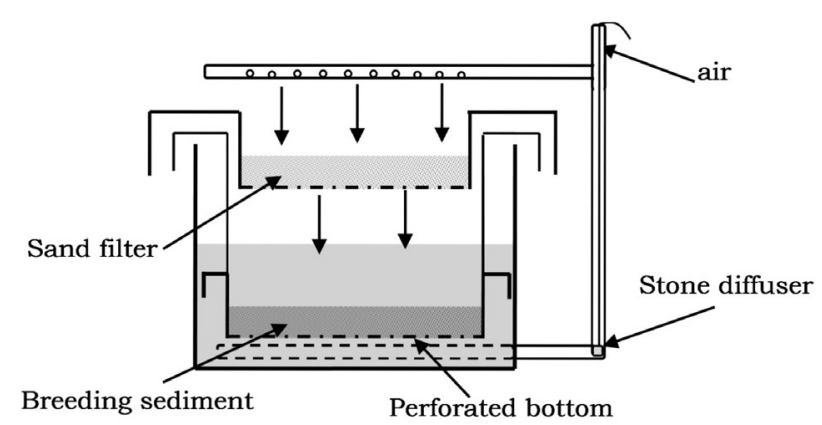

Fig. 1. - Schematic aquarium design used in the assays. 
maintained under constant oxygenation. Each aquarium was connected to a recirculation system (RAS) to allow continuous seawater flow and continuous aeration (see Fig. 1). Three different densities were used and replicated three times: high density (250 juveniles (juv.) corresponding to 1000 juv. $\mathrm{m}^{-2}$ ), medium density ( 150 juveniles corresponding to 500 juv. $\mathrm{m}^{-2}$ ) and low density (50 juveniles corresponding to 200 juv. $\mathrm{m}^{-2}$ ). The worms were placed inside each aquarium in a suspended tray (see Fig. 1) fitted with a perforated bottom. The water was circulated by the action of an air stone placed inside the circulation tube. The biological filter, composed of beach sand of different grain sizes, was also placed inside a tray at the top of the structure.

During the first $48 \mathrm{~h}$ of acclimatization to the laboratory conditions, the juvenile worms were able to settle (construct and establish burrows). The glass walls of the aquariums allowed the polychaetes inside them to be observed regarding their feeding and territorial behaviour. . Water temperature, salinity, dissolved oxygen, $\mathrm{pH}$, ammonium $\left(\mathrm{NH}_{4}^{+}\right)$and nitrites $\left(\mathrm{NO}_{2}^{-}\right)$were measured three times per week: temperature, dissolved oxygen and $\mathrm{pH}$ were measured by a multiparameter Hanna instruments model HI9829 water quality meter, salinity by a Hanna instruments HI83306 refractometer and ammonia and nitrites by two Hanna instruments kits, HI93700 and HI93708, respectively. In each aquarium, a mixture of crushed cockles $(20 \%)$, mussels $(60 \%)$ and shrimp $(20 \%)$ were provided daily, fresh and ad libitum, five times a week, representing an amount equivalent to $3 \%$ wet body weight. They were fed daily to avoid cannibalism. Excess food was removed three hours after being supplied. The diet was adjusted to account for increases in mean polychaete weight through time. Growth data were collected monthly for a sub-sample of $60 \%$ of the initial polychaete numbers for each density and aquarium after the beginning of the study. Morphological variables were only considered for whole individuals that did showed no signs of regeneration, broken segments or injuries. All polychaetes were also counted to determine mortality rate, and confrontation and territorial behaviour was observed through the existence of body lesions and broken and regenerating posterior segments.

In this work, total length (TL) and total dry weight (TDW) (Fig. 2) were adopted as biometric measures according to the following expressions (Castro 1993):

$$
\begin{gathered}
\mathrm{TL}=3.9303 \mathrm{WBS}^{1.3307} ; \mathrm{r}=0.9770, \mathrm{n}=192 \\
\mathrm{TDW}=0.0026 \mathrm{WBS}^{3.6894} ; \mathrm{r}=0.9845, \mathrm{n}=356
\end{gathered}
$$

where WBS (width of buccal segment) = LSB (put on legend).

Length was always determined from the number of setigers formed (SPB in Fig. 2). Segments were counted under a stereomicroscope equipped with a micrometric ocular at $20 \times$ magnification. The linear measurements of WBS obtained were taken under a

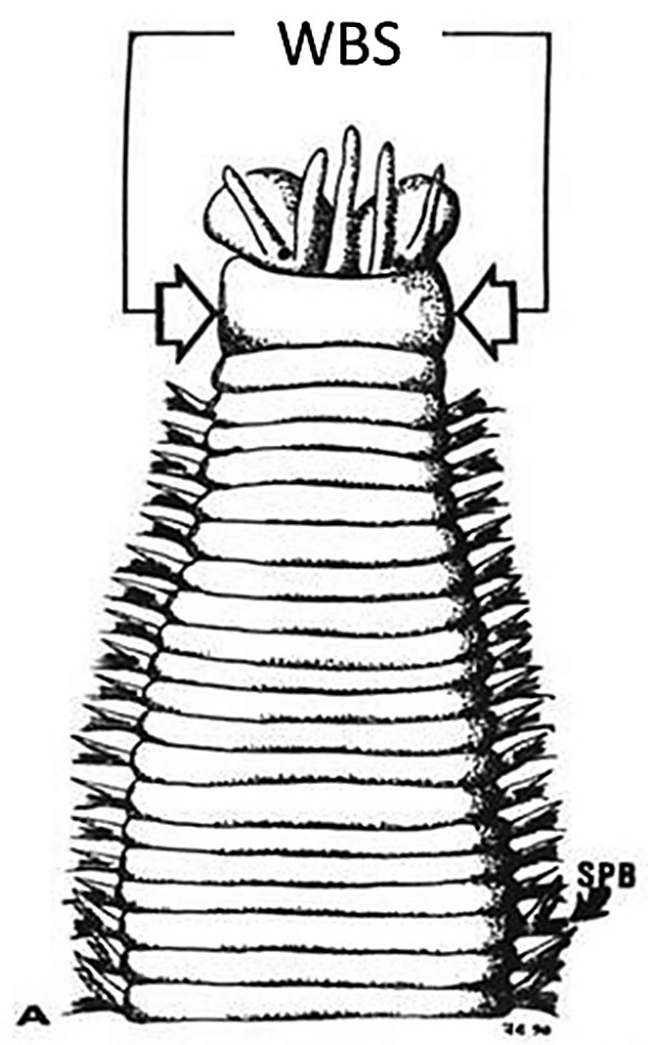

Fig. 2. - Dorsal view of the anterior region of Marphysa. sp., adapted from Garcês and Pereira (2010). B WBS = Width of buccal segment.

stereomicroscope equipped with a micrometric ocular at $2 \times$ magnification. The dimensions obtained were processed by the Qwin Lite 2.4 image-processing software system (Leica Microsystems Imaging Acquisition). Statistical analysis was performed using SPSS software (version 18; SPSS inc, Chicago, Il). The relationships between density and time and polychaete growth and survival were analysed by two-factor ANOVA followed by a Tukey test when significant differences were found.

\section{RESULTS}

\section{Water parameters}

During the study, the physico-chemical water parameters remained approximately constant. There were no significant differences between replicates $(\mathrm{p} \geq 0.05)$ for the parameters under study. However, over the 4 months gradual and slight variations in water temperature $\left(19-25^{\circ} \mathrm{C}\right)$, salinity $(30-33), \mathrm{pH}(7.6-8.1)$ ammonium (0.4-0.0) and nitrites (0.2-0.03) were nonetheless observed. The slight increase in ammonia and nitrite values during the experiment may be correlated with the confrontations and the associated mortality, but they did not reach high values that could have influenced this mortality. The control of these parameters reveals a perfect functioning of the biological filter. There was a higher dispersion value in dissolved ox- 


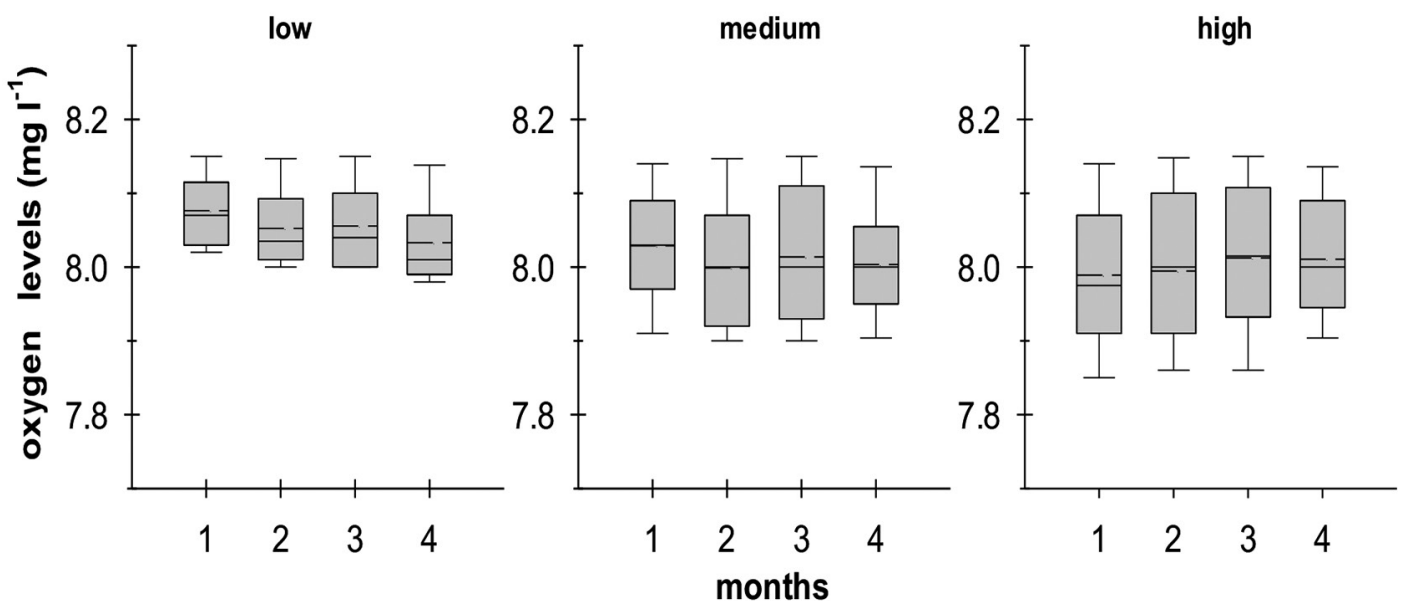

Fig. 3. - Dissolved oxygen concentrations (ppm) during the study at the three densities tested (low, medium and high).

Total growth
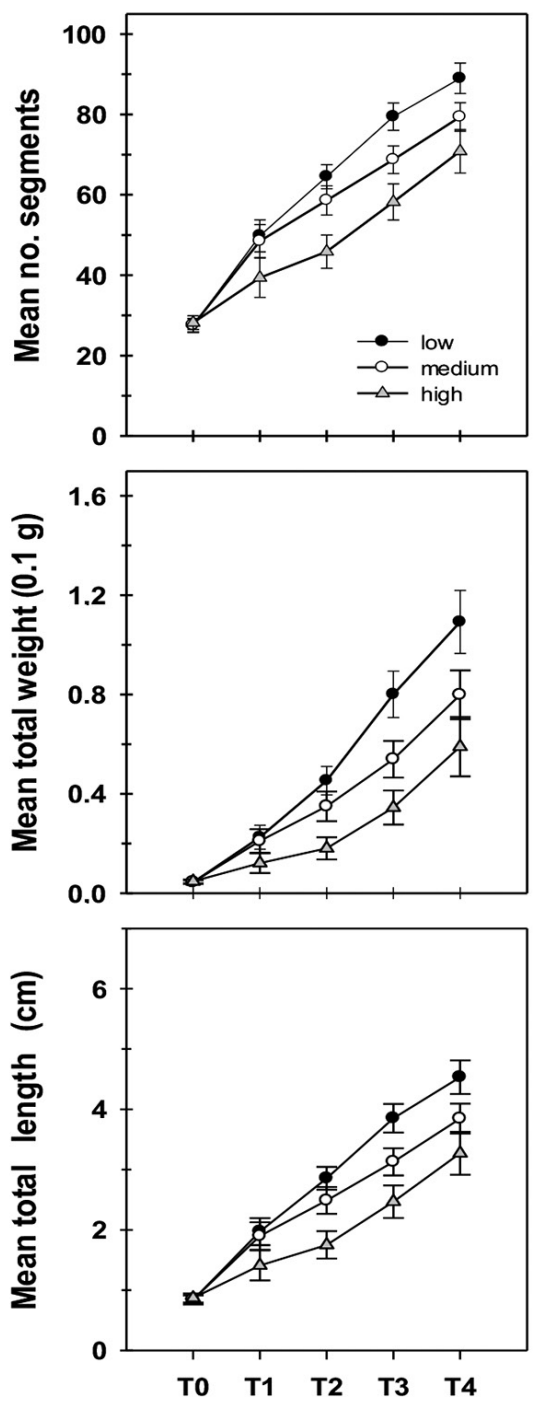

Monthly growth
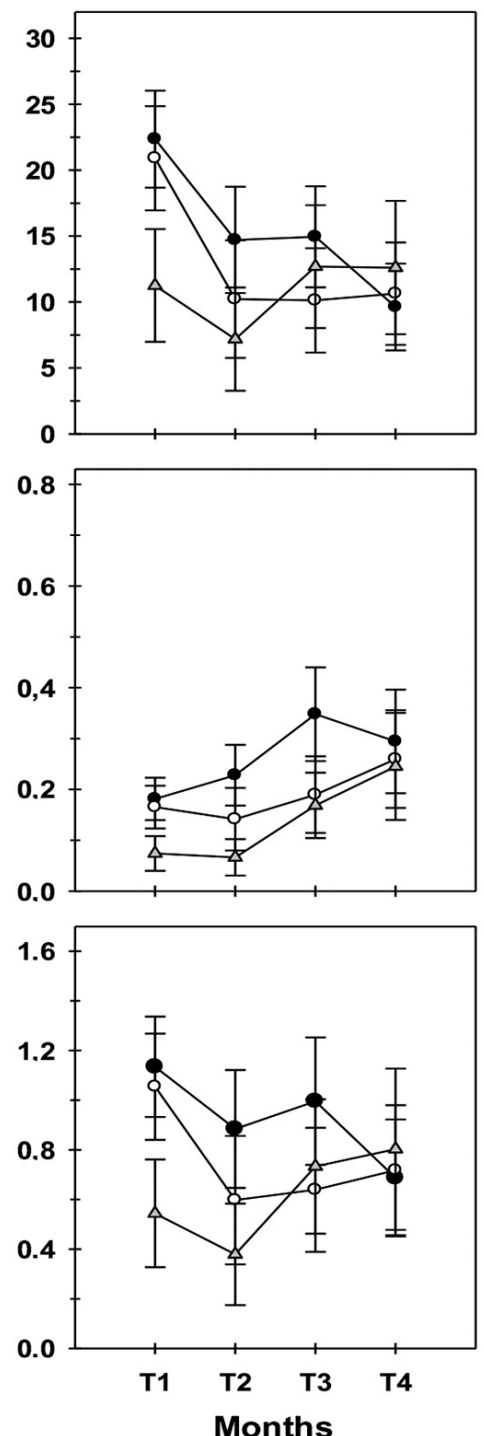

Specific growth rate
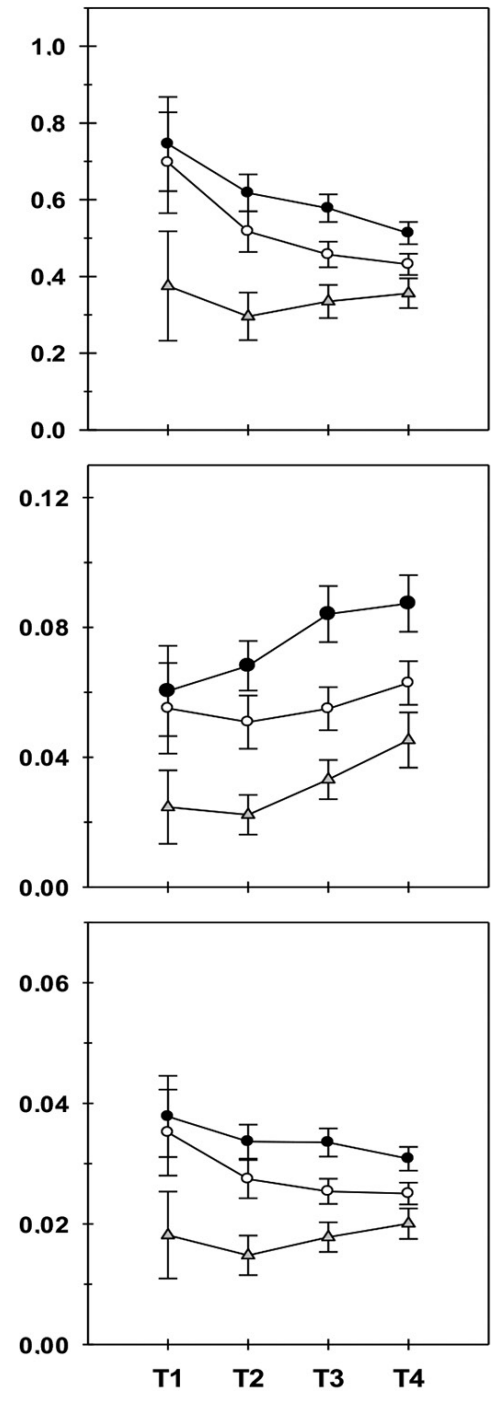

Fig. 4. - Monthly Growth of Marphysa "sp." at each density level (low, medium and high). $\mathrm{T}_{0}$, beginning of study; $\mathrm{T}_{1}$, period at month 1; and so on $\left(\mathrm{T}_{2}, \mathrm{~T}_{3}\right.$ and $\left.\mathrm{T}_{4}\right)$; monthly growth $\left(\mathrm{T}_{0}-\mathrm{T}_{\mathrm{n}-1}\right)$; specific growth rate $\left(\mathrm{T}_{0}-\mathrm{T}_{\mathrm{n}-1}\right) / 30$ days. 
ygen concentrations according to the density, which means an increased consumption by worms. However, there were no significant differences $(p \geq 0.05)$ between the replicates or in each density over time (Fig. 3 ).

\section{Feeding behaviour}

During this study, juveniles of Marphysa "sp." were observed to capture and ingest food particles on the sediment surface using their jaws, which are located ventrally as the worm moves over the substratum. The feed intake was observed to vary with density. At low density, the food particles were almost immediately consumed by the worms, which sometimes emerged completely from the gallery, getting fully exposed in the sediment surface. At medium and high densities, feeding was mainly at night and the worms never left the gallery, collecting food in a circular area and fleeing immediately into the gallery at the slightest sign of danger. At high density, the food was not entirely consumed during the first two months. However, it was not possible to determine the frequency with which searching activities resulted in particle consumption. Worms were observed seizing particles with their forceps jaws on many occasions, on both the substratum and over their tube or over the tube of a neighbour without confrontation.

\section{Somatic growth}

No significant differences were found in growth between replicates of each treatment during the four months of the study, although differences tended to be greater between replicates in the high-density treatment. A two-factor ANOVA showed significant density and time effects $(\mathrm{p}<0.001)$ and a significant interaction between density and time $(\mathrm{p}>0.001)$ for all the growth variables in every month. Means of total length, weight and number of segments were inversely related to density. In all treatments, juveniles grew steadily during the four months of the study (Fig. 4), but a comparison of the monthly average increase shows that the three parameters under study evolved differently for each density treatment.

At low and medium density levels, the estimated monthly increase in the number of segments was higher in the first month and decreased progressively over time. Under high density, however, there was a progressive increase in the number of segments from the second month. Only increase in weight was, in general, continuous at all densities.

After four months, at the lowest density the polychaetes formed $61.5 \pm 4.2$ segments, gained $0.1 \pm 0.01 \mathrm{~g}$ in dry weight and grew $4 \pm 0.2 \mathrm{~cm}$, at average density they formed $51.8 \pm 4$ segments $(0.08 \pm 0.008 \mathrm{~g}, 3 \pm 0.2$ $\mathrm{cm})$ and at high-density they formed $43 \pm 6$ segments $(0.05 \pm 0.01 \mathrm{~g}, 2.4 \pm 0.3 \mathrm{~cm})$ (see Fig. 4). It is noteworthy that at low density a significant decrease in the three parameters was observed in the last month ( $p>0.0001)$.

In this study, this high aggressiveness and territorial behaviour of Marphysa "sp." is well evidenced by the higher mortality (35\%) and greater incidence of

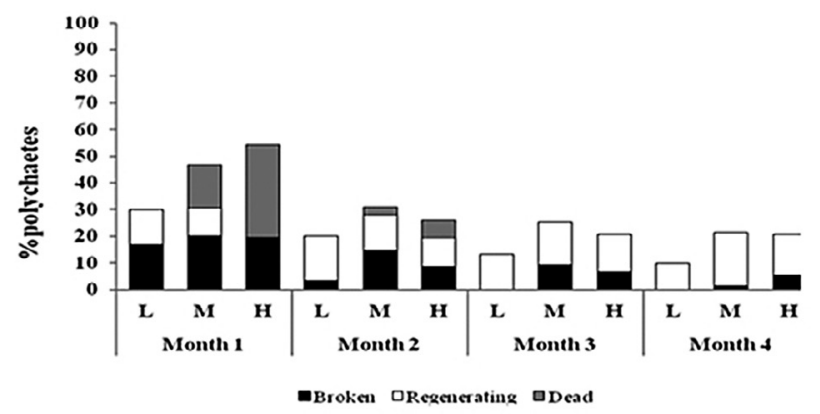

Fig. 5. - Monthly percentage occurrence of Marphysa "sp." Mortality and broken and regenerating posterior segments observed at each density level.

broken and regenerating posterior segments (19.3\%) observed under high density in the first month and by the presence of worms with lesions under low density (30\%) (Fig. 5).

Although the incidence of broken posterior segments was overall slightly higher $(16 \%)$ at medium density, mortality was much lower $(15 \%)$. The sharp decline both in mortality and in the incidence of broken posterior segments that occurred in the following months reveals that the worms tended towards an equilibrium density. However, confrontation never ceased, as shown by $5.2 \%$ and $1.3 \%$ of individuals with lesions in high and medium densities respectively in the fourth month of the study (Fig. 5). Average estimated mortality after four months was $44.9 \%, 18.9 \%$, and $0 \%$ at high, medium and low-density levels, respectively.

Despite this very high mortality, the average evolution of the existing population (Fig. 6) shows that significant differences in the number of individuals ( $p>0.001)$ continued to exist between the high and medium densities throughout the study, though it did not call into questiohn the existence of three densities.

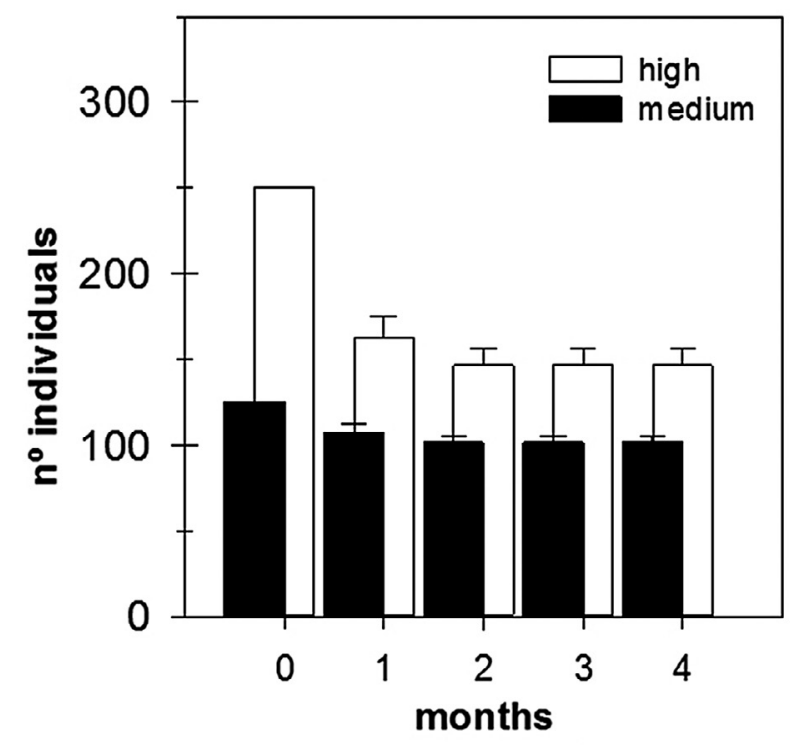

Fig. 6. - Marphysa "sp." population evolution at high and medium densities for four months. 
The existence of confrontations in the low-density tanks (with $16.7 \%$ and $13.3 \%$ of broken and regenerating individuals, respectively) confirms the high aggressiveness and territoriality evidenced by this species and suggests that, up to a certain point, the density can be higher than the optimum without necessarily resulting in death.

\section{DISCUSSION}

\section{Water parameters}

Most infaunal animals irrigate their burrows with oxygen-rich overlying water. They are active $20 \%$ to $50 \%$ of the time, alternating between active and quiescent periods in a rhythmic fashion, according to species (Garcês and Costa 2009, Galaktionov et al. 2004, Kristensen 2001). Marphysa "sp." dwells in L-shaped burrows and display vigorous bio-irrigation activity by pumping oxygenated water via peristaltic motions. According to Webber 1978, this genus has a high affinity to oxygen and high sensitivity to changes in $\mathrm{pH}$, suggesting a permanent life in galleries subject to low oxygen concentrations.

According to (Lemieux et al. 1997), the ability to explore a site largely depends on the ability to defend the gallery with a minimum of injuries. These authors have found a significant correlation between aerobic metabolism and the duration of the fight in Nereis virens. They argue that short-term confrontations are advantageous because they increase survival while still limiting the mobilization of anaerobic metabolism. On the other hand, high aerobic activity may be related to high metabolic rates, so the benefit of fights may be somewhat offset by a high metabolic costs for the antagonists, decreasing the energy available for growth and reproduction.

\section{Feeding behaviour}

Effects of increased density were also observed to lead to modifications in burrow shape. The absence of connections between the burrows as the density increased suggests that territoriality is certainly the main factor involved. A preference for the centre of the aquarium was observed during this study, i.e. colonization was made from the centre to the periphery of the aquaria at all densities. Scaps et al. (1998), in a study of Perinereis cultrifera, found that the area around the burrow opening is not defended and therefore does not constitute a territory, and they postulate that $P$. cultrifera probably competes for burrow space but may share food. By contrast, Levin (1982) and Taghon (1992) showed that spacing between neighbours in Spionid species can be affected by the particle supply mechanism and the source of food particles. In Paralvinella sulfincola, a polychaete worm living near deep-sea hydrothermal vents, Grelon et al. (2006) showed that the size of the territory and the control exerted over intruders depends on worm-density and individual body weight, reinforcing the importance of size and aggressiveness in the defence of the foraging area. The meth- od of feeding may also partly explain the observed behaviour. The use of sand and the type of diet, which was deposited directly onto the substrate surface, forced the worms to use their jaws to capture the food particles, therefore exposing their anterior region.

\section{Somatic growth}

The results obtained suggest that confrontation may have significantly $(\mathrm{p}<0.001)$ reduced growth, particularly at medium and high densities and in the first month (Figs 4, 5). The rising growth, which occurred at high density (Fig. 4) in the last two months, can be explained by the sharply declining number of individuals and therefore a decrease in confrontation with the concomitant establishment of undisputed territories. The same pattern was observed for the increased frequency of individuals injured, regenerated and killed. The negative density-dependent effects on growth of Marphysa "sp." juveniles are similar to those reported for several other polychaete species (Grelon et al. 2006, Safarik 2006, Nesto et al. 2012). The negative density-dependent effects on growth of juvenile and late juvenile $M$. sanguinea obtained by Parandavar et al. (2015) are similar to those obtained in our study. According to these authors, Marphysa sanguinea juveniles possess the ability to grow better at low density, and survival is negatively influenced by high rearing density. In the present study, survival was negatively influenced by high rearing density, as has also been already reported for $N$. arenaceodentata (Dillon et al. 1993), D. aciculata (Safarik et al. 2006) and Hediste diversicolor (Nesto et al. 2012). The decreasing survival percentages are likely to be related to the increasing intraspecific competition. Rearing density-related patterns in growth and mortality provide evidence for negative density-dependent interactions with neighbouring worms. According to Safarik et al. (2006), in Diopatra aciculate the negative effects of density on growth are due to intraspecific interactions, including competition for resources other than food. Territoriality can be fundamental for the survival of this species because the individual territory serves primarily for defence and refuge from predators, but also appears to be the primary foraging ground.

The existence of confrontations in the low-density tanks (with $16.7 \%$ and $13.3 \%$ of broken and regenerating individuals, respectively) confirms the high aggressiveness and territoriality evidenced by this species and suggests that, up to a certain point, the density can be higher than the optimum without necessarily resulting in death. However, in this study the worms were limited to a rigid physical space, and as they grow, they increase not only the body volume but also the territorial surface, obviously increasing the likelihood for encounters. Competition for space has also been shown for Neanthes arenaceodentata, which exhibit aggressive behaviour at high density, as demonstrated by an increase in the frequency of polychaetes regenerating posterior segments (Bridges et al. 1996).

Studies undertaken by (Esnault et al. 1990, Scaps et al. 1993) showed a similar reduction in growth, biomass and survival at high densities, even in the presence of 
abundant food. Stress associated with frequent handling of Hediste diversicolor and changes in water temperature and salinity have also been found to induce negative effects on growth (Scaps et al. 1993, Garcês and Pereira 2010). The decreasing survival percentages are likely to be related to the increasing intraspecific competition. Rearing density-related patterns in growth and mortality provide evidence for negative density-dependent interactions with neighbouring worms.

\section{CONCLUSIONS}

The results have shown that space occupation by Marphysa "sp." juveniles depends primarily on aggressive interaction. However, these observations may not apply to the entire life cycle of the species, which is known to be under the control of a greater range and complexity of movements.

The feeding method may also partly explain the observed behaviour. The use of sand and the type of diet, which was directly deposited onto the substrate surface, forced the worms to use their jaws to capture the food particles, therefore exposing their anterior region.

The results obtained in this study reveal that density has a significant effect $(\mathrm{p}<0.001)$ on somatic growth of Marphysa sp. juveniles, and that densities higher than 1000 juveniles per $\mathrm{m}^{2}$ cause high mortality (45\%). Finally, it is important to highlight that the very territorial and aggressive behaviour evidenced by Marphysa "sp." juveniles should be considered for aquaculture production. Further studies are required to determine the density effects for different developmental stages.

\section{ACKNOWLEDGEMENTS}

This study was carried out within the scope of the Diversiaqua II project (Mar2020 01/02/16 FMP006).

\section{REFERENCES}

Batista F M., Fidalgo e Costa. P., Matias D., et al. 2003. Preliminary results on the growth and survival of the polychaete Nereis diversicolor (OF Muller, 1776), when fed with faeces from the carpet shell clam Ruditapes decussatus (L., 1758). Bol. IEO 19: 443.

Beukema J.J. 1995. Long-term effects of mechanical harvesting of lugworms Arenicola marina on the zoobenthic community of a tidal flat in the Wadden Sea. Neth. J. Sea Res. 33: 219-227 https://doi.org/10.1016/0077-7579(95)90008-X

Birchenough S. 2013. Impact of bait collecting in Poole Harbour and other estuaries within the Southern IFCA District. Fisheries Challenge Fund-Project FES 186. Great Britain: UK Marine Management Organisation (MMO).

Bridges T.S., Farrar J.D., Gamble E.V., et al. 1996. Intraspecific density effects in Nereis (Neanthes) arenaceodentata Moore (Polychaeta: Nereidae). J. Exp. Mar. Biol. Ecol. 195: 221235.

https://doi.org/10.1016/0022-0981(95)00104-2

Cabral S., Alves A.S., Castro N., et al. 2019. Polychaete annelids as live bait in Portugal: Harvesting activity in brackish water systems. Ocean Coast. Manage. 181 https://doi.org/10.1016/j.ocecoaman.2019.104890

Carvalho S., Constantino R., Cerqueira M., et al. 2013. Shortterm impact of bait digging on intertidal macrobenthic assemblages of two south Iberian Atlantic systems. Est. Coast. Shelf Sci. 132: 65-76.

https://doi.org/10.1016/j.ecss.2011.06.017
Castro J.J. 1993. Impacte da exploração comercial e estrutura, dinâmica e produção da população de Marphysa sanguinea Annelida: Plychaeta) no estuário do Sado. Dissertation, University of Évora.

Cole V.J., Chick R.C., Hutchings P.A. 2018. A review of global fisheries for polychaete worms as a resource for recreational fishers: diversity, sustainability, and research needs. Rev. Fish Biol. Fish. 28: 543-565. https://doi.org/10.1007/s11160-018-9523-4

Elgetany A.H, El-Ghobashy A.E., Ghoneim A.M., et al. 2018. Description of a new species of the genus Marphysa (Eunicidae), Marphysa aegypti sp. n., based on molecular and morphological evidence. Invertebr. Zool. 15: 71-84. https://doi.org/10.15298/invertzool.15.1.05

Esnault G., Retière C., Lambert R. 1990. Food resource partitioning in a population of Nereis diversicolor (Annelida, Polychaeta) under experimental conditions. In: Barnes M, Gibson R.N. (eds). Trophic relationships in the marine Environment. Aberdeen University, pp. 453-467.

Gambi M.C., Castelli A., Giangrande A., et al. 1994. Polychaetes of commercial and applied interest in Italy: an overview. Mém. Mus. Nat. Hist. Natl. Paris 162: 593-602.

Galaktionov O.S., Meysman F.J.R., Middelburg J.J. 2004. Bioirrigation in marine sediments: ecological conclusions from numerical modeling. Paper presented at XXI ICTAM Conference, Warsaw Poland, 15-21 August.

Garcês J., Costa M.H. 2009. Trace metals in populations of Marphysa sanguinea (Montagu, 1813) from Sado estuary: effect of body size on accumulation. Sci. Mar. 73: 605-616. https://doi.org/10.3989/scimar.2009.73n3605

Garcês J.P., Pereira J. 2010. Effect of salinity on survival and growth of Marphysa sanguinea Montagu (1813) juveniles. Aquac. Int. 19: 523-530. http:://doi.org/10.1007/s10499-010-9368-x

Glasby C.J., Mandario M.A., Burghardt I., et al. 2019. A new species of the sanguinea-group Quatrefages, 1866 (Annelida: Eunicidae: Marphysa) from the Philippines. Zootaxa 4674: 264-282. https://doi.org/10.11646/zootaxa.4674.2.7

Grelon D., Morineaux M., Desrosiers G., et al. 2006.Feeding and territorial behavior of Paralvinella sulfincola, a polychaete worm at deep-sea hydrothermal vents of the Northeast Pacific Ocean. J. Exp. Mar. Biol. Ecol. 329: 174-186. https://doi.org/10.1016/j.jembe.2005.08.017

Hutchings P.A., Karageorgopoulos P. 2003. Designation of a neotype of Marphysa sanguinea (Montagu, 1813) and a description of a new species of Marphysa from eastern Australia. Hydrobiologia 496: 87-94. https://doi.org/10.1007/978-94-017-0655-1_9

Kristensen E. 2001. Impact of polychaetes (Nereis spp. and Arenicola marina) on carbon biochemistry in coastal sediments. Geochem. Trans. 12 https://doi.org/10.1186/1467-4866-2-92

Lavesque N., Daffe G., Bonifácio P., et al. 2017 A new species of the Marphysa sanguinea complex from French waters (Bay of Biscay, NE Atlantic) (Annelida, Eunicidae). ZooKeys 716: 1-17. https://doi.org/10.3897/zookeys.716.14070

Lavesque N., Daffe G., Grall J., et al. 2019. Guess who? On the importance of using appropriate name: case study of Marphysa sanguinea (Montagu, 1803). ZooKeys 859: 1-15. https://doi.org/10.3897/zookeys.859.34117

Lemieux H., Blier P.U., Dufresne F. et al. 1997. Metabolism and habitat competition in the polychaete Nereis virens. Mar. Ecol. Prog. Ser. 156: 151-156. https://doi.org/10.3354/meps156151

Levin L.A. 1982. Interference interactions among tube-dwelling polychaetes in a dense infaunal assemblage. J. Exp. Mar. Biol. Ecol. 65: 107-119. https://doi.org/10.1016/0022-0981(82)90039-9

Lewis C., Karageorgopoulos P. 2008. A new species of Marphysa (Eunicidae) from the western Cape of South Africa. J. Mar. Biol. Assoc. U.K. 88: 277-287. https://doi.org/10.1017/S002531540800009X

Nesto N., Simonini R., Prevedelli D., et al. 2012. Effects of diet and density on growth, survival and gametogenesis of Hediste diversicolor (O.F. Müller, 1776) (Nereididae, Polychaeta). Aquaculture 362-363: 1-9. https://doi.org/10.1016/j.aquaculture.2012.07.025 
Noda N., Tanaka R., Tsujino K., et al. 1994. Phosphocholine-bonded galactosylceramides having a tri-unsaturated long-chain base from the clam worm, Marphysa sanguinea. J. Biochem. 116: 435-442

https://doi.org/10.1093/oxfordjournals.jbchem.a124543

Olive P.J.W. 1993. Management of the exploitation of the lugworm Arenicola marina and the ragworm Nereis virens (Polychaeta) in conservation areas: the importance of population structure and recruitment processes. Aquat. Conserv. 3: $1-24$.

Olive P.J.W. 1999. Polychaete aquaculture and polychaete science: a mutual synergism. Hydrobiologia 402: 175-183 https://doi.org/10.1007/978-94-017-2887-4_9

Parandavar H., Kim K.H., Kim C.H. 2015. Effects of Rearing Density on Growth of the Polychaete Rockworm Marphysa sanguinea. Fish. Aquat. Sci. 18: 57-63. https://doi.org/10.5657/FAS.2015.0057

Pombo A., Baptista T., Granada L., et al. 2018. Insight into aquaculture's potential of marine annelid worms and ecological concerns: a review. Rev. Aquac. 12: 107-121. https://doi.org/10.1111/raq.12307

Reise K., Simon M., Herre E. 2001. Density-dependent recruitment after winter disturbance on tidal flats by the lugworm Arenicola marina. Helgol. Mar. Res. 55:161-165. https://doi.org/10.1007/s101520100076

Rosenberg R., Nilsson H.C., Hollertz K., et al. 1997. Density-dependent migration in an Amphiura filiformis (Amphiuridae, Echinodermata) infaunal population. Mar. Ecol. Prog. Ser. 159: 121-131

https://doi.org/10.3354/meps 159121
Safarik M., Redden A.M., Schreider M.J. 2006. Density-dependent growth of the polychaete Diopatra aciculate. Sci. Mar. 70S3: 337-341. https://doi.org/10.3989/scimar.2006.70s3337

Scaps P., Retière C., Desrosiers G., et al. 1993. Effets de la ration alimentaire, de la densité intraspécifique et des relations entre individus sur la croissance des juvéniles de l'espèce Nereis diversicolor (Annelida: Polychaeta). Can. J. Zool. 71: 424-430. https://doi.org/10.1139/z93-059

Scaps P., Brenot S., Retière C., et al.1998. Space occupation by the polychaetous annelid Perinereis cultrifera: Influence of substratum heterogeneity and intraspecific interactions on burrow structure. J. Mar. Biol. Ass. U.K. 78: 435-449. https://doi.org/10.1017/S0025315400041540

Taghon G.L. 1992. Effects of animal density and supply of deposited and suspended food particles on feeding, growth, and small-scale distribution of two spionid polychaetes. J. Exp. Mar. Biol. Ecol. 162: 77-95. https://doi.org/10.1016/0022-0981(92)90126-U

Watson G. J. Murray J.M., Schaefer M., et al. 2016. Bait worms: a valuable and important fishery with implications for fisheries and conservation management. Fish Fish. 18: 374-388. https://doi.org/10.1111/faf.12178

Webber R.E. 1978. Respiration. In: Mill P.J. (ed) Physiology of annelids, Academic Press, London, pp. 369-392.

Zajac R.N. 1996. The effects of intra-specific density and food supply on growth and reproduction in an infaunal polychaete, Polydora ligni Webster. J. Mar. Res. 44: 339-359. https://doi.org/10.1357/002224086788405310 